\title{
Research on the Supervision of Majority and Minority Shareholders on the Management Layer under Different Ownership Structures -Based on the Game Theory
}

\author{
Xiaohua Li \\ Business School of Sichuan University, Chengdu, Sichuan Province, China. \\ Audit office, North Sichuan Medical College, Nanchong, Sichuan Province, China.
}

Keywords: majority and minority shareholders, supervision, the management layer, game

\begin{abstract}
In companies with different ownership structures, majority shareholders and minority shareholders have different behaviors in the supervision of managerial personnel. This paper adopts game theory to analyze their behaviors, reveals the roles of majority and minority shareholders in the process of addressing principal-agent problems, and puts forward measures to solve principal-agent problems.
\end{abstract}

\section{Introduction}

Under different ownership structures, interest conflicts between majority and minority shareholders vary; conflicts between shareholders and company managers are also different. How to reasonably resolve these conflicts is a core issue in the financial governance and the management of companies. In theoretical research, following approaches should be adopted. Under the highly dispersed ownership structure, the goal of corporate management and corporate financial governance is to find an effective incentive and supervision system to maximize shareholders' rights and interests; under the centralized ownership structure, corporate governance and corporate financial governance should focus on resolving the dual principal-agent problem include the agency conflicts between shareholders and managers, and conflicts of interests between majority and minority shareholders. The reform of non-tradable shares has changed the past situation of only one dominant shareholder in the company. After the reform of non-tradable shares, many ownership structures have formed, such as "1 majority shareholder and $\mathrm{N}$ minority shareholders", "N majority shareholders and $\mathrm{N}$ minority shareholders" and "N minority shareholders". Under different ownership structures, shareholders' supervision on the managerial personnel may be different. It is of great significance to analyze the different roles of diversified shareholders in corporate governance and the supervision of managers through game theory, and find out methods which can solve the agency problem between shareholders and the management layer as well as the agency problem between majority shareholders and minority shareholders.

\section{Small and Medium Shareholders' "Free-Riding" Behaviors under the Dispersed Ownership Structure}

In companies with dispersed ownership structure, individual shareholders have three approaches to participate in corporate governance: forming a group with other shareholders and participating in corporate governance, so as to solve the agency problem of the management layer; "voting with feet"; turning a blind eye to the infringement of their interests. Individual shareholders' game processes in corporate governance and supervision of managers are as follows.

Hypothesis 1: the share held by a single shareholder is $\beta_{i}(\mathrm{i}=1,2,3 \ldots \mathrm{N})$; his effort in supervising managerial personnel is $P_{i}(\mathrm{i}=1,2,3 \ldots \mathrm{N})$; the cost is $\mathrm{C}_{i}=f\left(\mathrm{P}_{i}\right)$; $\mathrm{C}_{i}$ is an increasing function of $\mathrm{P}_{i}$. Under the dispersed ownership structure, cash flow rights are not centralized; it is difficult for individual small and medium shareholders to supervise managers' 
behaviors. Therefore, in order to effectively supervise corporate management, minority shareholders must take collective action. Then the cost of supervision will become $\mathrm{C}_{\text {Minority Shareholders }}=f\left(\sum_{i=1}^{n} P_{i}\right)$ while $f\left(\sum_{i=1}^{n} P_{i}\right) \geq \sum_{i=1}^{n} f\left(P_{i}\right)$

Hypothesis 2: All other conditions remain unchanged, the change of shareholders' wealth caused by supervision is $\Delta V=V_{\text {Supervision }}-V_{\text {Non-Supervision }}=f^{\prime}\left(\sum_{i=1}^{n} P_{i}\right),\left(f^{\prime}\left(\sum_{i=1}^{n} P_{i}\right)>0\right)$. In the formula, $\Delta R$ means the added value of shareholders' wealth caused by supervision; $V_{\text {Supervision }}$ represents enterprise income under the condition of shareholders' supervision on managerial personnel; $V_{\text {Non-Supervision }}$ represents enterprise income without shareholders' supervision on managerial personnel. Theoretically, according to shareholders' cash flow rights, incremental income should be distributed based on shareholders' cash flow rights. Thus, dividends shared by individual shareholders will be $\beta_{i} \frac{\Delta V}{\sum_{i=1}^{n} \beta_{i}} \quad(\mathrm{i}=1,2,3 \ldots \mathrm{N})$.

For shareholder 1, he assumes that most other shareholders have joined the supervision group; the supervision of managers has been carried out effectively. Then he weighs advantages and disadvantages and chooses the optimal strategy. This is a static game problem with complete information.

If he chooses to join the supervision group, the earning will be $\Omega=\beta_{1} \frac{\Delta V}{\sum_{i=1}^{n} \beta_{i}}-f\left(P_{1}\right)$

If he refuses to join the supervision group, since he assumes that other shareholders have joined the group, his earning will be $\Omega=\beta_{1} \frac{\Delta V}{\sum_{i=1}^{n} \beta_{i}}$. Obviously, the best strategy is not to join the supervision group.

In another case, shareholder 1 assumes that most other shareholders have not joined the supervision group and the supervision of managers has not been carried out effectively. If he chooses to join the supervision group, the income will be $\Omega=\beta_{1} \frac{f^{\prime}(0)}{\sum_{i=1}^{n} \beta_{i}}-f\left(P_{1}\right)=-f\left(P_{1}\right)$. If he chooses not to join the supervision group, the earning will be 0. Obviously, the best strategy is still not to join the supervision group.

From above analysis, it can be seen that in companies with highly dispersed ownership structures, shareholders have no motivations in supervising managers' behaviors. In reality, shareholders are more reluctant to take the initiative in supervising since the joint supervision of shareholders requires more transaction costs. "Free-riding" and "voting with feet" are best strategies.

\section{Minority Shareholders' "Free-Riding" Behaviors under the Highly Concentrated Ownership Structure}

In companies with centralized ownership structure, controlling shareholders and individual minority shareholders take following game strategies in corporate governance and combating infringement.

Hypothesis 1: the stock of controlling shareholders is $\alpha$; the share of a single minority 
shareholder is $\beta_{i}(\mathrm{i}=1,2,3 \ldots \mathrm{N})$. The total shares of small and medium shareholders is $\sum_{i=1}^{n} \beta_{i}=$ 1- $\alpha$. There is a principal-agent relationship between managers and shareholders. In order to protect their interests, the principal shareholders may supervise the behavior of managers. The effort made by the controlling shareholder in supervising the managerial personnel is $P_{\text {Controlling Shareholder }}$; the cost is $\mathrm{C}_{\text {Controlling Shareholder }}=f\left(\mathrm{P}_{\text {Controlling Shareholder }}\right) ; \mathrm{C}_{\text {Controlling Shareholder }}$ is an incremental function of $P_{\text {Controlling Shareholder }}$ The effort made by a single minority shareholder in supervising the managerial personnel is $P_{i}(\mathrm{i}=1,2,3 \ldots \mathrm{N})$; the cost is $\mathrm{C}_{i}=f\left(\mathrm{P}_{i}\right) ; \mathrm{C}_{i}$ is also an increasing function of $\mathrm{P}_{i}$.

Hypothesis 2: In modern enterprises, shareholders' supervision of the management layer can improve corporate performance and increase shareholders' wealth. Then we assume that other conditions remain unchanged, the change of shareholders' wealth caused by supervision is $\Delta V=V_{\text {Supervision }}-V_{\text {Non-Supervision }}=f^{\prime}\left(\mathrm{p}_{\text {Controlling Shareholder }}, \sum_{i=1}^{n} P_{i}\right)$, in which $\Delta R$ means the added value of shareholders' wealth caused by supervision; $V_{\text {Supervision }}$ represents enterprise income under the condition of shareholders' supervision on the managerial personnel;

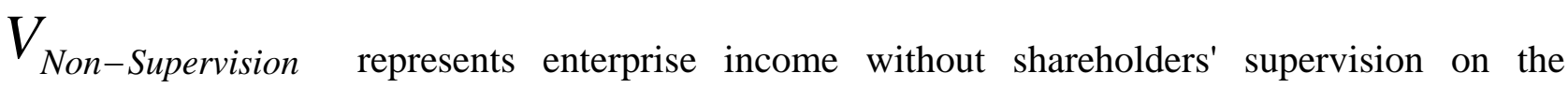
managerial personnel. Theoretically, according to shareholders' cash flow rights, incremental income should be distributed based on shareholders' cash flow rights. Thus, the controlling shareholders should enjoy the income of $a \frac{\Delta V}{\sum^{n}}$. The income of a single minority shareholder $a+\sum_{i=1}^{n} \beta_{i}$

is $\beta_{i} \frac{\Delta V}{a+\sum_{i=1}^{n} \beta_{i}} \quad(\mathrm{i}=1,2,3 \ldots \mathrm{N})$.

Under the ownership structure of controlling shareholders, we can regard the process as a two-stage static game model. Since controlling shareholders take the leading role in enterprises, small and medium shareholders usually observe their behaviors first and then make their own choice.

Controlling shareholders can choose to supervise managers' behaviors or not.

Situation 1: If the controlling shareholders choose to supervise, minority shareholders have two choices; supervision and non-supervision.

If both controlling shareholders and minority shareholders choose to supervise, the earnings functions will be:

$$
\begin{aligned}
& \Omega_{\text {Controlling Shareholder }}=\alpha \frac{f^{\prime}\left(\mathrm{P}_{\text {Controlling Shareholder }}, \sum_{i=1}^{n} P_{i}\right)}{\alpha+\sum_{i=1}^{n} \beta_{i}}-f\left(P_{\text {Controlling Shareholder }}\right) \\
& \Omega_{\text {One Minority Shareholder }}=\beta_{1} \frac{f^{\prime}\left(\mathrm{P}_{\text {Controlling Shareholder }}, \sum_{i=1}^{n} P_{i}\right)}{\alpha+\sum_{i=1}^{n} \beta_{i}}-f\left(P_{1}\right)
\end{aligned}
$$

If the controlling shareholder chooses to supervise while a single minority shareholder chooses not to supervise, the income functions will be: 


$$
\begin{aligned}
& \Omega_{\text {Controlling Shareholder }}=\alpha \frac{f^{\prime}\left(\mathrm{P}_{\text {Controlling Shareholder }}, \sum_{i=1}^{n} P_{i}\right)}{\alpha+\sum_{i=1}^{n} \beta_{i}}-f\left(P_{\text {Controlling Shareholder }}\right) \\
& \Omega_{\text {one minority shareholder }}=\beta_{1} \frac{f^{\prime}\left(\mathrm{P}_{\text {controlling shareholder }}, \sum_{i=1}^{n} P_{i}\right)}{\alpha+\sum_{i=1}^{n} \beta_{i}}
\end{aligned}
$$

Obviously, for a single minority shareholder, when the controlling shareholder chooses to supervise, for him, the benefit of non supervision $\beta_{1} \frac{f^{\prime}\left(\mathrm{P}_{\text {Controlling Shareholder }}, \sum_{i=1}^{n} P_{i}\right)}{\alpha+\sum_{i=1}^{n} \beta_{i}}$ is bigger than the benefit of supervision $\beta_{1} \frac{f^{\prime}\left(\mathrm{P}_{\text {Controlling Shareholder }}, \sum_{i=1}^{n} P_{i}\right)}{\alpha+\sum_{i=1}^{n} \beta_{i}}-f\left(P_{1}\right)$. In order to maximize their own interests, rational small and medium shareholders will choose not to supervise.

Situation 2: If the controlling shareholders choose not to supervise, minority shareholders still have two choices, supervision and non-supervision.

The controlling shareholder chooses not to supervise while minority shareholder chooses to supervise. Under this ownership structure, it is difficult of minority shareholders to supervise managers' behaviors effectively because of their limited shares; their income functions will be:

$$
\Omega_{\text {Controlling Shareholder }}=\alpha \frac{f^{\prime}\left(\sum_{i=1}^{n} P_{i}\right)}{\alpha+\sum_{i=1}^{n} \beta_{i}} ; \quad \Omega_{\text {One Minority Shareholder }}=\beta_{1} \frac{f^{\prime}\left(\sum_{i=1}^{n} P_{i}\right)}{\alpha+\sum_{i=1}^{n} \beta_{i}}-f\left(P_{1}\right)
$$

If both controlling shareholders and the single minority shareholder choose not to supervise, their income functions will be:

$$
\Omega_{\text {Controlling Shareholder }}=\alpha \frac{f^{\prime}\left(\sum_{i=1}^{n} P_{i}\right)}{\alpha+\sum_{i=1}^{n} \beta_{i}} ; \quad \Omega_{\text {One Minority Shareholder }}=\beta_{1} \frac{f^{\prime}\left(\sum_{i=1}^{n} P_{i}\right)}{\alpha+\sum_{i=1}^{n} \beta_{i}}
$$

For a single minority shareholder, when the controlling shareholder chooses not to supervise, the benefit of non supervision $\beta_{1} \frac{f^{\prime}\left(\sum_{i=1}^{n} P_{i}\right)}{\alpha+\sum_{i=1}^{n} \beta_{i}}$ is bigger than that of the supervision $\frac{f_{1}\left(\sum_{i=1}^{n} P_{i}\right)}{\alpha+\sum_{i=1}^{n} \beta_{i}}-f\left(P_{1}\right)$. Therefore, rational small and medium shareholders will not supervise in order to maximize their interests.

\section{Minority Shareholders' "Free-Riding" Behaviors in Companies with Several Relative Controlling Shareholders}

In companies with relatively centralized ownership structure, a single controlling shareholder cannot make a significant impact on the resolution of shareholders' meeting through the appointment or removal of board members or other means. But two or a few relative controlling 
shareholders together can have enough shares to significantly impact the resolution of shareholders' meeting through the appointment or removal of board members or other means. Because of the high cost of "voting by foot" and the high risks of company lose due to managers' poor operation, several shareholders may choose to supervise the managerial personnel jointly. In this case, the game process of relative controlling shareholders and individual minority shareholders in corporate governance and supervision of managers are as follows.

Hypothesis 1: The number of relative controlling shareholders is $\mathrm{K}(2 \leq \mathrm{K} \leq 10)$; the share of a single controlling shareholder is $a_{k}$; the share of a single minority shareholder is $\beta_{i} \quad(\mathrm{i}=1,2,3 \ldots$ $\mathrm{N}$ ); the sum of small and medium shareholders' shares is $\sum_{i=1}^{n} \beta_{i}=1-\sum_{k=2}^{10} \alpha_{k}$. There is a principal-agent relationship between managers and shareholders. In order to protect the interests of shareholders, the principal shareholders may supervise the behavior of managers. We further assume that the effort made by a single controlling shareholder in supervising the managerial personnel is $P_{k}$; the cost is $\mathrm{C}_{k}=f\left(\mathrm{P}_{k}\right) ; \mathrm{C}_{k}$ is an incremental function of $\mathrm{P}_{k}$. The effort made by a single monitory shareholder in supervising the managerial personnel is $P_{i} \quad(\mathrm{i}=1,2,3 \ldots \mathrm{N})$; the cost is $\mathrm{C}_{i}=f\left(\mathrm{P}_{i}\right) ; \mathrm{C}_{i}$ is also an increasing function of $\mathrm{P}_{i}$.

Hypothesis 2: In modern enterprises, shareholders' supervision on managerial personnel can improve corporate performance and increase shareholders' income. If other conditions remain unchanged, the change of a shareholder's wealth caused by supervision will be $\Delta V=V_{\text {Supervision }}-V_{\text {Non-Supervision }}=f^{\prime}\left(\sum_{k=2}^{10} p_{k}, \sum_{i=1}^{n} P_{i}\right)>0$, in which $\Delta R$ means the added value of the shareholder's wealth caused by supervision; $V_{\text {Supervision }}$ represents enterprise income under shareholders' supervision on managerial personnel; $V_{\text {Non-Supervision }}$ represents enterprise income without shareholders' supervision. Theoretically, according to shareholders' cash flow rights, incremental income should be distributed based on shareholders' cash flow rights. Thus, the controlling shareholders should enjoy the income of $\alpha_{k} \frac{f^{\prime}\left(\sum_{k=2}^{10} p_{k}, \sum_{i=1}^{n} P_{i}\right)}{\sum_{k=2}^{10} \alpha_{k}+\sum_{i=1}^{n} \beta_{i}}$. The income of a single minority shareholder should be $\beta_{i} \frac{\Delta V}{a+\sum_{i=1}^{n} \beta_{i}} . \quad(\mathrm{i}=1,2,3 \ldots . . \mathrm{N})$

We can consider the game process under this ownership structure as a two-stage dynamic game model. Relative controlling shareholders need to consider shareholders' groups and transaction costs, and then make their choices. Afterwards, according to the relative controlling shareholders' decision, small and medium shareholders make their own choices.

For relative controlling shareholders, there are two choices: supervision and non supervision.

If relative controlling shareholders choose to supervise, $\Omega_{\alpha_{1}}=\alpha_{1} \frac{f^{\prime}\left(\sum_{k=2}^{10} p_{k}, \sum_{i=1}^{n} P_{i}\right)}{\sum_{k=2}^{10} \alpha_{k}+\sum_{i=1}^{n} \beta_{i}}-f\left(P_{1}\right)$. Since it is difficult for a single minority shareholder to supervise the behavior of managers, if relative controlling shareholders do not supervise managerial personnel, the principal-agent problem may occur and lead to infringement shareholders' interests. $f^{\prime}(0)$ may become zero or negative. At that 
time, the return function of relative controlling shareholders' earning $\Omega_{\alpha_{1}}=\alpha_{1} \frac{f^{\prime}(0)}{\sum_{k=2}^{10} \alpha_{k}+\sum_{i=1}^{n} \beta_{i}}$ may become zero or negative. Therefore, supervision is the optimal choice for relative controlling shareholders.

For small and medium shareholders, if the relative controlling shareholders choose to supervise, the income of supervision will be $\Omega_{\beta_{1}}=\beta_{1} \frac{f^{\prime}\left(\sum_{k=2}^{10} p_{k}, \sum_{i=1}^{n} P_{i}\right)}{\sum_{k=2}^{10} \alpha_{k}+\sum_{i=1}^{n} \beta_{i}}-f\left(P_{\text {One Minority Shareholder }}\right)$; the income of non-supervision will be $\Omega_{\beta_{1}}=\beta_{1} \frac{f^{\prime}\left(\sum_{k=2}^{10} p_{k}, \sum_{i=1}^{n} P_{i}\right)}{\sum_{k=2}^{10} \alpha_{k}+\sum_{i=1}^{n} \beta_{i}}$. If the relative controlling shareholder
chooses not to supervise, the income of supervision will be $\Omega_{\beta_{1}}=\beta_{1} \frac{f^{\prime}(0)}{\sum_{k=2}^{10} \alpha_{k}+\sum_{i=1}^{n} \beta_{i}}-f\left(P_{\text {one minority shareholder }}\right) \quad\left(f^{\prime}(0) \leq 0\right) ;$ the income of non-supervision will be $\Omega_{\beta_{1}}=\beta_{1} \frac{f^{\prime}(0)}{\sum_{k=2}^{10} \alpha_{k}+\sum_{i=1}^{n} \beta_{i}}\left(f^{\prime}(0) \leq 0\right)$. Non-supervision is still the optimal choice.

\section{Analyses of Game Results and Suggestions}

Following conclusions can be drawn from above analyses. (1) Regardless of ownership structure, minority shareholders have little enthusiasm in participating in corporate governance. On one hand, small and medium shareholders have few shares; participation in corporate governance has high cost and low income. On the other hand, they can reduce risks by "voting with feet" when their rights and interests are infringed. (2) The share transfer of controlling shareholders and relative controlling shareholders is restricted by the market and relevant regulations. Majority shareholders have motivations in participating in corporate governance and gaining benefits from the growth of the company. In the face of possible principal-agent problems of the management layer, they are actively involved in the supervision of managers. In the process of corporate governance, controlling shareholders and relative controlling shareholders can supervise and control the behaviors of managers, since they have information superiority and strong power (power obtained by holding more shares). (3) The "free-riding" behaviors of small and medium shareholders increase the costs of controlling shareholders and relative controlling shareholders in corporate governance, while the benefits are shared by all stockholders. In spite of contributions, major shareholders do not have normal channels to obtain benefits. Controlling shareholders and relative controlling shareholders may seek for control benefits from other channels. Since controlling shareholders and relative controlling shareholders have paid more costs in corporate governance but have no special compensation, and they have gained information superiority and super control power in the process of corporate governance, they objectively ask for cost reimbursement. Some majority shareholders even infringe the interests of minority shareholders in this process.

In the process of corporate governance, to solve the problem of dual agency, minority shareholders' costs in participating in corporate governance should be reduced; the cost of controlling shareholders and relative controlling shareholders should be compensated. A mechanism 
needs to be established to protect the rights and interests of small and medium shareholders. First, small and medium shareholders need convenient and low cost channels to exercise their supervisory powers, so as to increase their enthusiasm in corporate governance and reduce free-riding behaviors. Second, reasonable control benefit mechanism and compensation mechanism should be built for controlling shareholders and relative controlling shareholders. Third, supervision departments in the securities market should strengthen supervision and punish these controlling and relative controlling shareholders which violate regulations or infringe the benefits of small and medium shareholders; a mechanism should be established and improved to compensate minority shareholders with impairment of benefit.

\section{References}

[1] W.Y. Zhang, Game Theory and Information Economics, Shanghai Sanlian bookstore, Shanghai, 2004.

[2] G.F. Feng, Double principal-agent theory: another analysis framework of listed companies' governance, J. Economic Research Journal. 12 (2004) 16-25. 